\title{
Feed efficiency and carcass and meat quality characteristics of bulls finished on diets containing varied proportions of wheat straw and wet sugar beet pulp
}

\author{
S. Yüksel ${ }^{1}$, M. Yanar ${ }^{2 \#}$, L. Turgut ${ }^{2}$, A. Özlütürk ${ }^{1}$, S. Kopuzlu ${ }^{1}$ and E. Sezgin ${ }^{1}$ \\ ${ }^{1}$ Eastern Anatolian Agricultural Research Institute, 25250, Erzurum, Turkey \\ ${ }^{2}$ Department of Animal Science, College of Agriculture, Atatürk University, 25240, Erzurum, Turkey
}

\begin{abstract}
Fifteen young Holstein Friesian bulls (18 mo of age) were divided into three groups of five. All groups were fed a diet consisting of $60 \%$ concentrate and $40 \%$ roughage. The control (C) group received a mixture of dry meadow hay, dry lucerne and wheat straw as roughage. The second and third treatment groups were fed a similar mixture of roughage partially substituting wheat straw with wet sugar beet pulp (SBP) at levels of $4 \%$ and $8 \%$ on a dry matter (DM) basis, respectively. Dry matter intake and feed efficiency ratio (kg DM intake/kg weight gain) of the C group were significantly higher than those of the $4 \%$ SBP and $8 \%$ SBP groups. Slaughter and carcass traits indicated that there were no significant differences between dietary treatments. The inclusion of $8 \%$ SBP significantly improved panel ratings for tenderness, juiciness, beef flavour intensity and general acceptance, as well as number of chews before swallowing and the Warner Bratzler Shear value. Proximate analysis of the meat did not demonstrate differences between meat from the bulls fed $\mathrm{C}$ and the SBP diets. It was concluded that wheat straw could be replaced by $8 \%$ SBP in the finishing diet for young Holstein Friesian bulls in order to improve feed efficiency and sensory quality characteristics of their meat.
\end{abstract}

Keywords: Sugar beet pulp, finishing, Holstein Friesian bulls, carcass, meat quality

${ }^{\#}$ Corresponding author. E-mail: myanar@atauni.edu.tr

\section{Introduction}

Among factors contributing to the profitability of beef production, efficiency of feed utilization is undoubtedly the most important, since feed represents $75 \%$ or more of the total variable cost of animal production. Finishing diets for cattle in Turkey generally consist of forages (wheat straw or grass- or lucerne hay) and concentrates based on grains (carbohydrate sources) and sunflower meal and cotton seed meal (protein sources). Cattle producers in the country also use the by-products (wet sugar beet pulp and molasses) from the sugar industry in order to reduce feed costs. The sugar beet pulp (SBP) has great importance in beef cattle feeding programmes, since it has highly digestible fibre that may encourage the growth of the cellulolytic and hemicellulolytic microorganisms (Fluharty \& Dehority, 1995). This, in turn, can increase the extent of digestion of the dietary forage. The SBP also contains a relatively high available energy (total digestible nutrients [TDN] of $720 \mathrm{~g} / \mathrm{kg}$ ) content, and therefore could be used as a roughage source in finishing diets (Lardy \& Anderson, 2003).

Nutritional factors have significant influences on the structural and biochemical characteristics of carcass and on meat quality traits. The modification of ration composition and level of feeding can alter muscle characteristics at slaughter which can then affect the sensorial attributes of the meat (Geay et al., 2001). As a result, using alternative feed sources aimed at increasing animal productivity and profitability is desirable only if meat quality and consumer acceptance are maintained.

The feeding value of the SBP with other forages has been evaluated in beef cattle by Rush \& Pelt (1999), Park et al. (2001) and Cuvelier et al. (2006). Oflaz et al. (2005) studied growth, carcass and meat traits of young Karayaka rams fed sugar beet pulp that partially substituted grass hay as forage. However, comparable information about the finishing performance, and carcass and meat quality traits of young, dairy bulls fed diets where wet SBP partially substituted wheat straw is lacking. The present study was undertaken to investigate daily weight gain, feed efficiency, carcass and slaughter traits and organoleptic properties of meat from Holstein Friesian bulls fed diets where wheat straw was partially replaced by SBP. 


\section{Material and Methods}

The study was carried out at the Eastern Anatolian Agricultural Research Institute, Erzurum, Turkey. Fifteen Holstein Friesian bulls (18 months old) were divided into three groups of five animals of similar body weights. The bulls were housed in a tethered stall barn containing individual pens furnished with feeders and automatic drinkers. All groups were offered a diet containing 60\% concentrate and $40 \%$ roughage (as fed basis). The roughage consisted of a mixture of dry meadow hay including mixture of grasses, dry lucerne, wheat straw, and wet SBP. The concentrate was made up of barley, maize, wheat, wheat bran, cotton seed meal, sunflower seed meal and salt. The first group (control group $=\mathrm{C}$ ) received a mixture of dry meadow hay, dry lucerne and wheat straw as roughage. The second and third treatment groups were fed a mixture of roughage in which SBP at levels of $4 \%$ and $8 \%$ on dry matter (DM) basis, respectively, partially substituted wheat straw in the diet (Table 1). Hence, there were three experimental groups $(\mathrm{C}$; $4 \%$ SBP, $8 \%$ SBP) in the study. The animals were fed individually and were adapted to the finishing diets over a period of two weeks. All bulls had ad libitum access to the concentrate and roughage mixture during the whole finishing period. The DM (AOAC, 1990; method 934.01), crude protein as Kjeldahl nitrogen (AOAC, 1995; method 990.03), ether extract (AOAC, 1990; method 920.39), ash (AOAC, 1990; method 9420.5) and acid detergent fibre (ADF) and neutral detergent fibre (NDF) (Tyznik, 1992) levels in the diet were determined (Table 2).

After a $12 \mathrm{~h}$ fast by removing both feed and water, the bulls were weighed on two consecutive days at the beginning and end of the fattening period to determine average initial and final weights. The bulls were also weighed at 14-d intervals throughout the trial and amount of diet offered was adjusted based upon their live weights. Feed intake, daily weight gain and feed efficiency were calculated. Amount of feed offered to each bull was recorded and refusals were collected and weighed daily in order to determine feed intake. The trial lasted five months.

Table 1 Composition of the roughage mixture with different levels of sugar beet pulp (SBP) fed to finishing dairy bulls to evaluate impact on feed efficiency and meat sensory qualities

\begin{tabular}{lccc}
\hline & \multicolumn{3}{c}{ Dietary treatment } \\
\cline { 2 - 4 } Ingredients (\% dry matter basis) & Control & $4 \%$ SBP & $8 \%$ SBP \\
\hline Sugar beet pulp & - & 4 & 8 \\
Wheat straw & 20 & 16 & 12 \\
Lucerne hay & 40 & 40 & 40 \\
Meadow hay & 40 & 40 & 40 \\
\hline
\end{tabular}

Table 2 Chemical composition of feeds on a dry matter (DM) basis used for finishing of the young Holstein bulls

\begin{tabular}{lcccccc}
\hline Feeds & $\begin{array}{c}\text { Dry matter } \\
(\mathrm{DM})(\mathrm{g} / \mathrm{kg})\end{array}$ & $\begin{array}{c}\text { Crude protein } \\
(\mathrm{g} / \mathrm{kg}, \mathrm{DM})\end{array}$ & $\begin{array}{c}\text { Ether extract } \\
(\mathrm{g} / \mathrm{kg}, \mathrm{DM})\end{array}$ & $\begin{array}{c}\text { Ash } \\
(\mathrm{g} / \mathrm{kg}, \mathrm{DM})\end{array}$ & $\begin{array}{c}\text { ADF } \\
(\mathrm{g} / \mathrm{kg}, \mathrm{DM})\end{array}$ & $\begin{array}{c}\text { NDF } \\
(\mathrm{g} / \mathrm{kg}, \mathrm{DM})\end{array}$ \\
\hline Concentrate & 923.1 & 169.0 & 38.0 & 77.0 & - & - \\
Dry Meadow hay & 937.0 & 110.1 & 33.3 & 97.1 & 401 & 605 \\
Dry Lucerne hay & 930.1 & 173.0 & 21.1 & 105.0 & 312 & 422 \\
Wheat straw & 931.0 & 32.0 & 8.0 & 97.1 & 469 & 625 \\
Sugar beet pulp & 127.0 & 94.2 & 78.0 & 181.0 & 256 & 548 \\
\end{tabular}

ADF - Acid detergent fibre; NDF - Neutral detergent fibre.

All bulls were slaughtered at a commercial slaughterhouse. The head, hide, feet, liver, lungs, spleen, kidney and heart were removed and weighed. Hot carcass weights and carcass measurements (length, width 
of round, length of round, width of round from medial side, and thoracic depth) were also obtained (Yener et al., 1988). Dressing percentage was calculated as a ratio of hot carcass weight to the live weight obtained in the slaughterhouse. A carcass was split into halves before a chill period at $4{ }^{\circ} \mathrm{C}$ for $24 \mathrm{~h}$. The carcasses were then cut at the $12^{\text {th }}$ and $13^{\text {th }}$ rib intersection and the depth of subcutaneous fat, the area $\left(\mathrm{cm}^{2}\right)$ of the longissimus dorsi (LD) and marbling score were determined at the cut site. The scale used for marbling evaluation ranged from 1 to $18\left(1=\right.$ slight $^{-}, 2=\operatorname{slight~}^{0}, 3=\operatorname{slight}^{+}, 4=$ small $^{-}, 5=$ small $^{0}, 6=$ small $^{+}$, $7=$ modest $^{-}, 8=$ modest $^{0}, 9=$ modest $^{+}, 10=$ moderate $^{-}, 11=$ moderate $^{0}, 12=$ moderate $^{+}, 13=$ slightly $^{+}$ abundant, $14=$ slightly abundant ${ }^{0}, 15=$ slightly abundant $^{+}, 16=$ abundant $^{-}, 17=$ abundant $^{0}$, $18=$ abundant $^{+}$). The weights of the kidneys, heart and pelvic fat were recorded and expressed as a proportion of carcass weight. All carcasses were evaluated for yield grade (a numerical value from 1 to 5 based upon the yield of boneless, closely trimmed retail cuts from the round, loin, rib and chuck of the beef carcass) and cutability (percentage of boneless, closely trimmed retail cuts from the round, loin, rib and chuck of the beef carcass) was predicted by using a mathematical equation (Boggs \& Merkel, 1984).

Meat samples were taken from the LD, quadriceps $(\mathrm{Q})$ and gluteus medius $(\mathrm{GM})$ muscles of the carcasses at $24 \mathrm{~h}$ post-mortem. The muscle portions were cut perpendicularly to the muscle fibres into two pieces for chemical and sensory analysis. The meat samples for organoleptic analysis were weighed, individually enclosed in water-impermeable, polyethylene bags, sealed and completely immersed in a water bath $\left(90{ }^{\circ} \mathrm{C}\right)$ until the internal temperature of each sample reached $70{ }^{\circ} \mathrm{C}$, as outlined by Yanar (1994). Cooked samples were dried between layers of paper towels for $5 \mathrm{~min}$ to remove cooking drip. Cooking yield was determined by dividing cooked weight by uncooked weight. The cooked meat samples were cut into eight cubes $(2 \times 2 \times 2 \mathrm{~cm})$ and served to eight panel members, each with a cup of tap water to reduce carryover effects. Panel members have been trained in the sensory evaluation of meat. They were not informed about the research project. Panel members independently evaluated each sample for degree of tenderness, flavour intensity, juiciness, general acceptability and number of chews before swallowing. Scores, except for the number of chews, were obtained using a nine point hedonic scale $(9=$ extremely tender, $1=$ extremely tough; 9 = extremely strong beef flavour, $1=$ extremely weak flavour; $9=$ extremely juicy, $1=$ extremely dry; 9 = extremely high general acceptability, $1=$ extremely low acceptability). For mechanical assessment of tenderness, cooked beef samples were cooled to $20^{\circ} \mathrm{C}$ and six cores were removed parallel to longitudinal orientation of muscle fibres for Warner-Bratzler Shear (WBS) force measurements. Raw beef samples from the LD, Q, and GM muscles were analysed according to Ockerman (1985) for moisture, crude protein, ash and ether extractable lipids.

Data were analyzed statistically using the general linear model procedure of the SPSS computer programme (SPSS, 2004, version 13.0, Chicago, USA). The data on performance, slaughter, carcass traits and carcass measurements were analysed by a model that included the effect of diet. The chemical composition, sensory panel and cooking yield data were analysed statistically using a model that included the effect of diet and muscle. Diet and muscle interactions were excluded from the final model because they were not significant, according to a preliminary statistical analysis. The Duncan method was applied for comparison of subclass means when F-tests for main effects were significant. Correlations between panel rating scores and WBS value and number of chews before swallowing were also determined.

\section{Results and Discussion}

Although the final weight and daily and total weight gains of the $4 \%$ SBP-fed bulls were numerically greater than the $\mathrm{C}$ and $8 \%$ SBP groups (Table 3), differences between the diet groups were not significant (P >0.05). Similar findings were reported by Cuvelier et al. (2006) who observed insignificant differences between SBP and cereal-fed, young beef bulls in terms of live weight gain and final weight.

In the present study, increasing the amount of SBP in the diet of the young bulls resulted in a decrease in DM intake $(\mathrm{P}<0.05)$ and an improved feed efficiency $(\mathrm{P}<0.05$, Table 3$)$. The $\mathrm{C}$ group consumed $16.2 \%$ and $27.1 \%$ more DM than 4\% SBP and $8 \%$ SBP groups, respectively. This is in agreement with the results of Park et al. (2001) and Bauer et al. (2007) who reported that the addition of SBP in finishing diets of beef steers tended to decrease DM intake. Voelker \& Allen (2003) suggested that stimulation of stretch receptors in the ruminal wall signalled satiety and was likely a predominant factor in decreasing DM intake due to added SBP. They also reported that water content of ruminal digesta increased when adding beet pulp to the diet. Therefore, ruminal digesta volume, weight and water holding capacity contributed to the limitation of DM intake by distension. 
Table 3 Least squares means ( \pm s.e.) for finishing traits of dairy bulls fed diets where sugar beet pulp (SBP) partially replaced wheat straw in the diet

\begin{tabular}{lrrr}
\hline & \multicolumn{3}{c}{ Diets } \\
\cline { 2 - 4 } Traits & \multicolumn{1}{c}{ Control } & \multicolumn{1}{c}{$4 \% \mathrm{SBP}^{2}$} & \multicolumn{1}{c}{$8 \% \mathrm{SBP}^{2}$} \\
\hline Initial weight $(\mathrm{kg})$ & $317.0 \pm 23.17$ & $323.3 \pm 25.91$ & $317.4 \pm 23.17$ \\
Final weight $(\mathrm{kg})$ & $501.8 \pm 22.40$ & $522.0 \pm 25.05$ & $499.0 \pm 22.40$ \\
Daily weight gain $(\mathrm{kg})$ & $1.23 \pm 0.07$ & $1.32 \pm 0.08$ & $1.21 \pm 0.07$ \\
Daily feed intake $(\mathrm{kg} \mathrm{DM})$ & $12.64^{\mathrm{a}} \pm 0.31$ & $10.59^{\mathrm{b}} \pm 0.35$ & $9.22^{\mathrm{c}} \pm 0.31$ \\
Feed efficiency $^{1}$ & $10.27^{\mathrm{A}} \pm 0.67$ & $8.02^{\mathrm{B}} \pm 0.75$ & $7.62^{\mathrm{B}} \pm 0.67$
\end{tabular}

\footnotetext{
$\overline{a, b, c}$ Values within rows with different superscripts differ significantly at $\mathrm{P}<0.05$.

$\mathrm{A}, \mathrm{B}, \mathrm{C}$ Values within rows with different superscripts differ significantly at $\mathrm{P}<0.01$.

${ }^{1}$ Feed efficiency $=\mathrm{DM}$ intake $(\mathrm{kg}) /$ weight gain $(\mathrm{kg}) ;{ }^{2} \%$ SBP on a dry basis.
}

Table 4 Least squares means ( \pm s.e.) for slaughter weights, carcass traits and non-carcass components of dairy bulls finished on diets containing graded levels of sugar beet pulp (SBP)

\begin{tabular}{|c|c|c|c|}
\hline & \multicolumn{3}{|c|}{ Diets* } \\
\hline Traits & Control & $4 \% \mathrm{SBP}^{* *}$ & $8 \% \mathrm{SBP} * *$ \\
\hline Slaughter weight (kg) & $497.2 \pm 22.39$ & $512.5 \pm 25.03$ & $489.2 \pm 22.39$ \\
\hline Hot carcass weight (kg) & $277.0 \pm 14.54$ & $292.5 \pm 16.26$ & $273.3 \pm 14.54$ \\
\hline Dressing $(\%)$ & $55.7 \pm 0.65$ & $56.0 \pm 0.72$ & $55.9 \pm 0.65$ \\
\hline Marbling score & $3.75 \pm 0.53$ & $3.77 \pm 0.53$ & $3.80 \pm 0.48$ \\
\hline Pelvic fat (kg) & $0.26 \pm 0.03$ & $0.25 \pm 0.04$ & $0.28 \pm 0.03$ \\
\hline Kidney fat (kg) & $5.44 \pm 0.52$ & $4.20 \pm 0.58$ & $4.64 \pm 0.52$ \\
\hline $\mathrm{KPH}$ fat $(\%)$ & $4.34 \pm 0.18$ & $3.81 \pm 0.21$ & $3.83 \pm 0.18$ \\
\hline $\mathrm{LD}$ area $\left(\mathrm{cm}^{2}\right)$ & $70.9 \pm 5.46$ & $75.1 \pm 6.10$ & $73.6 \pm 5.46$ \\
\hline Fat thickness over LD (mm) & $3.12 \pm 0.30$ & $3.50 \pm 0.33$ & $2.76 \pm 0.30$ \\
\hline Cutability $(\%)$ & $47.6 \pm 0.28$ & $47.7 \pm 0.32$ & $48.0 \pm 0.28$ \\
\hline Yield grade & $3.96 \pm 0.12$ & $3.92 \pm 0.13$ & $3.81 \pm 0.12$ \\
\hline \multicolumn{4}{|c|}{ Non-carcass components as a percentage of slaughter weight $(\%)$} \\
\hline Hide & $6.43 \pm 0.22$ & $6.64 \pm 0.24$ & $6.68 \pm 0.22$ \\
\hline Head & $4.76 \pm 0.10$ & $4.88 \pm 0.11$ & $5.17 \pm 0.10$ \\
\hline Four feet & $1.89 \pm 0.04$ & $1.81 \pm 0.04$ & $1.87 \pm 0.04$ \\
\hline Heart & $0.411 \pm 0.051$ & $0.428 \pm 0.057$ & $0.514 \pm 0.051$ \\
\hline Lung & $1.120 \pm 0.065$ & $1.212 \pm 0.072$ & $1.203 \pm 0.065$ \\
\hline Liver & $1.563 \pm 0.073$ & $1.651 \pm 0.082$ & $1.573 \pm 0.073$ \\
\hline Kidneys & $0.138 \pm 0.023$ & $0.157 \pm 0.026$ & $0.185 \pm 0.023$ \\
\hline Spleen & $0.194 \pm 0.013$ & $0.236 \pm 0.015$ & $0.229 \pm 0.013$ \\
\hline
\end{tabular}

* Differences between diets were not statistically significant $(\mathrm{P}>0.05)$; **\% SBP on a dry basis.

$\mathrm{KPH}$ - kidney, pelvic and heart fat; LD - Longissimus dorsi muscle.

Increased feed efficiency could have been due to improved DM and NDF digestibility when a more digestible fibre source, SBP, substituted the less digestible wheat straw. Hoffman et al. (2006) also reported that the NDF digestibility of SBP is twice as high as that of wheat straw.

Increasing the proportion of SBP in the diets of the dairy bulls by substituting wheat straw did not affect slaughter weight, carcass characteristics or proportions of non-carcass components significantly $(\mathrm{P}>0.05$, Table 4). Yield grade and cutability values were also not adversely affected by the inclusion of SBP in the diets. Similar effects of SBP in finishing rations of beef bulls were reported by Marsh et al. (2001) and Cuvalier et al. (2006). Park et al. (2001) observed that hot carcass weights, LD areas, yield grade 
and cutability values of beef steers in the control, $8.5 \%$ SBP, and 12.5\% SBP groups did not differ significantly. There were also insignificant differences in fat thickness over the LD, marbling score and percentage of the kidney, heart and pelvic fat (KPH \%) as a result of an increased level of beet pulp in the diets of beef cattle (Bauer et al., 2007). In the present study marbling scores were also not affected by dietary treatment (Table 4).

Increasing the amount of SBP in the finishing diets did not have an adverse effect on carcass length, width of round, length of round, width of round from medial side or thoracic depth (Table 5). The carcass measurements were within the normal range for Holstein Friesian bulls fattened in Europe (Keane, 2003). Similarly, there were no significant differences in the carcass DM, fat, ash and protein levels between the dietary treatment groups (Table 6). Type of muscle, however, affected percentage of DM $(\mathrm{P}<0.05)$ and fat ( $\mathrm{P}<0.01)$ content. The fat content of the LD muscle was significantly higher than that of the GM muscle. This result is in accordance with the findings of Ozluturk et al. (2004). In general, the chemical composition of the carcasses was within the ranges recorded by Gariepy et al. (1999) and Unlu et al. (2008).

Consumer evaluation of palatability is an important assessment of beef quality. The most significant criteria are juiciness, tenderness, flavour intensity and general acceptability. Tenderness is one of the most important sensory attributes by which consumers judge meat quality (Stolowski et al., 2006). Although this criterion strongly depends upon post-mortem treatments such as aging and cooling, adjustments in nutritional factors may be used as in vivo strategies to optimise beef quality (Sami et al., 2006). The results of the present study revealed that meat from carcasses of the animals fed diets containing 8\% SBP received higher ratings $(\mathrm{P}<0.01)$ for panel tenderness score and lower WBS value and number of chews before swallowing

Table 5 Least squares means ( \pm s.e.) for carcass measurements of the dairy bulls fed diets that partially replaced wheat straw with $\mathrm{SBP}^{1}$ at $4 \%$ and $8 \%$ on a dry matter basis

\begin{tabular}{lccc}
\hline & \multicolumn{3}{c}{ Diets* } \\
\cline { 2 - 4 } Traits & Control & $4 \%$ SBP & $8 \%$ SBP \\
\hline & $139.2 \pm 2.8$ & $142.6 \pm 3.1$ & $142.1 \pm 2.8$ \\
Carcass length $(\mathrm{cm})$ & $73.8 \pm 1.1$ & $73.5 \pm 1.3$ & $74.9 \pm 1.1$ \\
Length of the round $(\mathrm{cm})$ & $46.5 \pm 0.6$ & $48.1 \pm 0.7$ & $47.5 \pm 0.6$ \\
Thoracic depth $(\mathrm{cm})$ & $40.1 \pm 3.2$ & $34.7 \pm 3.6$ & $34.8 \pm 3.2$ \\
Width of the round $(\mathrm{cm})$ & $25.2 \pm 0.6$ & $26.7 \pm 0.7$ & $26.2 \pm 0.6$ \\
Width of the round from medial side (cm) & & \\
\hline
\end{tabular}

* Differences between diets were not statistically significant $(\mathrm{P}>0.05)$.

SBP - sugar beet pulp.

Table 6 Least squares means ( \pm s.e.) of chemical analysis (\%) of the muscles of the bulls fed diets partially substituting wheat straw with wet $\mathrm{SBP}^{1}$ at $4 \%$ and $8 \%$ on a dry matter basis

\begin{tabular}{lcccccc}
\hline & \multicolumn{3}{c}{ Diets* } & \multicolumn{3}{c}{ Muscles } \\
\cline { 2 - 7 } & Control & $4 \%$ SBP & $8 \%$ SBP & LD & GM & Q \\
\hline Dry matter & $24.9 \pm 0.2$ & $24.4 \pm 0.3$ & $24.3 \pm 0.2$ & $25.0^{\mathrm{a}} \pm 0.2$ & $24.1^{\mathrm{b}} \pm 0.2$ & $24.5^{\mathrm{ab}} \pm 0.2$ \\
Fat & $1.7 \pm 0.2$ & $1.8 \pm 0.3$ & $1.9 \pm 0.2$ & $2.3^{\mathrm{A}} \pm 0.2$ & $1.3^{\mathrm{B}} \pm 0.2$ & $1.8^{\mathrm{AB}} \pm 0.2$ \\
Protein & $19.9 \pm 0.3$ & $20.4 \pm 0.3$ & $20.1 \pm 0.3$ & $20.6 \pm 0.3$ & $20.0 \pm 0.3$ & $19.8 \pm 0.3$ \\
Ash & $1.1 \pm 0.01$ & $1.1 \pm 0.01$ & $1.0 \pm 0.01$ & $1.0 \pm 0.01$ & $1.1 \pm 0.01$ & $1.1 \pm 0.01$ \\
\hline
\end{tabular}

* Differences between diets were not statistically significant $(\mathrm{P}>0.05)$.

${ }^{a}, b, c$ Muscle values within rows with different superscripts differ significantly at $\mathrm{P}<0.05$.

A, B, C Muscle values within rows with different superscripts differ significantly at $\mathrm{P}<0.01$.

SBP - sugar beet pulp; LD - Longissimus dorsi, GM - gluteus medius and Q - quadriceps muscles. 
than both the $\mathrm{C}$ and $4 \%$ SBP groups ( $\mathrm{P}<0.01$, Table 7). The inclusion of wet SBP in the diet also increased panel juiciness scores $(\mathrm{P}<0.01)$. Additionally, beef flavour intensity and general acceptability scores of the $8 \%$ of SBP fed group were higher than in the other treatment groups $(\mathrm{P}<0.01)$. Combining all treatment groups, important variations in panel tenderness $(\mathrm{P}<0.05)$, juiciness, flavour intensity and general acceptability ( $\mathrm{P}<0.01$ ) were consistent between muscles (Table 7). Longissimus dorsi had higher sensory panel ratings for tenderness, flavour intensity, juiciness, and general acceptability than the Q muscle. This result is in accordance with findings of Jurie et al. (2007). The tenderness of the three muscles was also evaluated by WBS value and number of chews before swallowing. The values for LD were better than those for muscles from round, but the differences were not statistically significant.

Table 7 Least squares means ( \pm s.e.) for sensory panel scores, number of chews and cooking yield of the muscles of the bulls fed diets that partially replaced wheat straw with $\mathrm{SBP}^{1}$ at $4 \%$ and $8 \%$ on a dry matter basis

\begin{tabular}{lcccccc}
\hline & \multicolumn{3}{c}{ Diets } & \multicolumn{3}{c}{ Muscles } \\
\cline { 2 - 7 } & Control & $4 \%$ SBP & $8 \%$ SBP & LD & GM & Q \\
\hline Tenderness & & & & & \\
Juiciness & $4.8^{\mathrm{A}} \pm 0.1$ & $5.4^{\mathrm{B}} \pm 0.1$ & $6.8^{\mathrm{C}} \pm 0.1$ & $5.9^{\mathrm{a}} \pm 0.1$ & $5.7^{\mathrm{ab}} \pm 0.1$ & $5.4^{\mathrm{b}} \pm 0.1$ \\
Flavour intensity & $5.0^{\mathrm{A}} \pm 0.1$ & $5.4^{\mathrm{B}} \pm 0.1$ & $5.9^{\mathrm{C}} \pm 0.1$ & $5.6^{\mathrm{A}} \pm 0.1$ & $5.5^{\mathrm{A}} \pm 0.1$ & $5.1^{\mathrm{B}} \pm 0.1$ \\
General acceptability & $5.5^{\mathrm{A}} \pm 0.1$ & $5.8^{\mathrm{B}} \pm 0.1$ & $6.3^{\mathrm{C}} \pm 0.1$ & $6.2^{\mathrm{A}} \pm 0.1$ & $5.9^{\mathrm{A}} \pm 0.1$ & $5.6^{\mathrm{B}} \pm 0.1$ \\
NCBS & $5.4^{\mathrm{A}} \pm 0.1$ & $5.9^{\mathrm{B}} \pm 0.1$ & $6.5^{\mathrm{C}} \pm 0.1$ & $6.2^{\mathrm{A}} \pm 0.1$ & $6.0^{\mathrm{A}} \pm 0.1$ & $5.6^{\mathrm{B}} \pm 0.1$ \\
WBS & $55.9^{\mathrm{A}} \pm 1.5$ & $48.3^{\mathrm{B}} \pm 1.7$ & $40.2^{\mathrm{C}} \pm 1.5$ & $45.4 \pm 1.6$ & $49.7 \pm 1.6$ & $49.1 \pm 1.6$ \\
Cooking yield & $11.3^{\mathrm{A}} \pm 0.5$ & $10.2^{\mathrm{A}} \pm 0.6$ & $6.7^{\mathrm{B}} \pm 0.5$ & $8.5 \pm 0.5$ & $9.4 \pm 0.5$ & $10.3 \pm 0.5$ \\
& $69.6 \pm 1.9$ & $72.8^{2} \pm 2.1$ & $75.6 \pm 1.9$ & $77.2^{\mathrm{a}} \pm 1.9$ & $70.7^{\mathrm{b}} \pm 1.9$ & $70.2^{\mathrm{b}} \pm 1.9$
\end{tabular}

${ }^{a, b, c}$ Within diets or muscles, value differences within rows with different superscripts differ significantly at $\mathrm{P}<0.05$;

A, B, C Within diets or muscles, value differences within rows with different superscripts differ significantly at $\mathrm{P}<0.01$.

SBP - Sugar beet pulp; NCBS - Number of chews before swallowing; WBS - Warner Bratzler Shear score.

LD - Longissimus dorsi, GM - gluteus medius and Q - quadriceps muscles.

Significant correlations $(\mathrm{P}<0.01)$ for panel tenderness score $(\mathrm{r}=-0.709)$ and number of chews before swallowing $(r=0.649)$ with WBS value demonstrated that data from mechanical (objective) and organoleptic assessments of tenderness (subjective) were in agreement. Panel juiciness score was closely related with WBS force value $(r=-0.578)$, tenderness score $(r=0.774)$, number of chews before swallowing $(\mathrm{r}=-0.576)$ and acceptability score $(\mathrm{r}=0.790)$. Panel juiciness score had a significant correlation with flavour intensity $(\mathrm{r}=0.704)$. Overall correlations revealed that panel tenderness, general acceptance and flavour intensity scores were mostly related to moisture content of meat and are in agreement with the findings of May et al. (1992) and Ozluturk et al. (2004).

\section{Conclusion}

The present study demonstrated that feed efficiency and sensory attributes of beef from Holstein bulls fed 8\% SBP were significantly improved over those of bulls fed no SBP. Carcass and slaughter traits as well as chemical composition of meat were not influenced adversely by the addition of SBP to the bulls' diet. Our data suggested that wheat straw in the finishing diet of dairy bulls could be replaced by $8 \%$ of SBP which is both environmentally sound and an economically advantageous feed.

\section{References}

AOAC, 1990. Association of Official Analytical Chemists. Official Methods of Analysis. $15^{\text {th }}$ ed. A.O.A.C. Arlington, Virginia, USA.

AOAC, 1995. Association of Official Analytical Chemists. Official Methods of Analysis. $16^{\text {th }}$ ed. A.O.A.C. Arlington, Virginia, USA. 
Bauer, M.L., Schimek, D.E., Reed, J.J., Caton, P.T., Berg, P.T. \& Lardy, G.P., 2007. Influence of pressed beet pulp and concentrated separator by-product on intake, gain, efficiency of gain, and carcass composition of growing and finishing beef steers. J. Anim. Sci. 85, 2290-2297.

Boggs, D.L. \& Merkel, A.R., 1984. Live Animal Carcass Evaluation and Selection Manual. Kendall/Hunt Publishing Co. Dubuque, Iowa, USA.

Cuvelier, C., Cabaraux, J.F., Dufrasne, I., Clinquart, A., Hocquette, J.F., Istasse, L. \& Hornick, J.L., 2006. Performance, slaughter characteristics and meat quality of young bulls from Belgian Blue, Limousin and Aberdeen Angus breeds fattened with a sugar-beet pulp or a cereal-based diet. Anim. Sci. 82, 125-132.

Fluharty, F.L. \& Dehority, B.A., 1995. Effects of sugar beet pulp and corn as energy supplements for cattle fed forage diets on diet digestibility and ruminal microorganisms. Special Circular - Ohio Agricultural Research and Development Center Issue: No.156, The Ohio State University, Columbus, Ohio, USA. pp. 51-55.

Gariepy, C., Seoane, J.R., Cloteau, C., Martin, J.F. \& Roy, G.L., 1999. The use of double-muscled cattle breeds in terminal crosses: Meat quality. Can. J. Anim. Sci. 79, 301-308.

Geay, Y., Bauchart, D, Hocquette, J. \& Culioli, J., 2001. Effect of nutritional factors on biochemical, structural and metabolic characteristics of muscles in ruminants, consequences on dietetic value and sensorial qualities of meat. Reprod. Nutr. Dev. 41, 1-26.

Hoffman, P.C., Lundberg, K.M., Bauman, L.M. \& Shaver, R.D., 2006. NDF digestibility: Reference values for forages, by products and total mixed rations. Focus on Forage 5, 1-2.

Jurie, C., Picard, B., Hocquette, J.F., Dransfield, E., Micol, D. \& Listrat, A., 2007. Muscle and meat quality characteristics of Holstein and Saler cull cows. Meat Sci. 77, 459-466.

Keane, M.G., 2003. Beef production from Holstein-Friesian bulls and steers of New Zealand and European/American descent, and Belgian Blue $\times$ Holstein-Friesians, slaughtered at two weights. Livest. Prod. Sci. 84, 207-218.

Lardy, G. \& Anderson, V., 2003. Alternative Feeds for Ruminants. AS-1182, NDSU Extension Service, North Dakota State University, Fargo, North Dakota, USA.

Marsh, S.P., Edmond, S.L. \& Witt, M., 2001. Comparison of pressed sugar beet pulp ensiled with dried maize distillers grains against a ration based on barley and soy bean meal for fast finishing suckled beef bulls. In: Proc. British Society of Animal Science 2001. March 2000, Scarborough, UK. p. 113.

May, S.G., Dolezal, H.G., Gill, D.R., Ray, F.K. \& Buchanan, D.S., 1992. Effects of days fed, carcass grade traits, and subcutaneous fat removal on post mortem muscle characteristics and beef palatability. J. Anim. Sci. 70, 444-453.

Ockerman, H.W., 1985. Quality control of post mortem muscle tissue, carcass quantity, quality and color evaluation (13 ${ }^{\text {th }}$ ed., Vol. 1). The Ohio State University, Department of Animal Science, Columbus, Ohio, USA. pp. 10-41.

Oflaz, M., Ocak, N., Erener, G., Cam, M.A. \& Garipoglu, A.V., 2005. Growth, carcass and meat characteristics of Karayaka growing rams fed sugar beet pulp, partially substituting for grass hay as forage. Meat Sci. 70, 7-14.

Ozluturk,A., Tuzemen, N., Yanar, M., Esenbuga, N. \& Dursun, E., 2004. Fattening performance, carcass traits and meat quality characteristics of calves sired by Charolais, Simmental and Eastern Anatolian Red sired mated to Eastern Anatolian Red dams. Meat Sci. 67, 463-470.

Park, J., Rush, I., Milton, T. \& Weichental, B., 2001. The effect of feeding pressed sugar beet pulp in beef cattle feedlot finishing diets. 2001 Beef cattle report Agricultural Research Division, Institute of Agriculture and Natural Resources, University of Nebraska, Lincoln, Nebraska, USA. pp. 67-69.

Rush, I. \& Pelt, B.V., 1999. Performance of yearling steers fed beet pulp or chicory pulp rations. University of Nebraska Cooperative Extension MP 71, Lincoln, Nebraska, USA. pp.1-4.

Sami, A.S., Koegel, J., Eichinger, H., Freudenreich, P. \& Schwarz, F.J., 2006. Effects of dietary energy source on meat quality and eating quality attributes and fatty acid profile of Simmental bulls. Anim. Res. 55, 287-299.

SPSS, 2004. SPSS for Windows. Released 13.0 SPSS Inc., Chicago, Illinois, USA.

Stolowski, G.D., Baird, B.E., Miller, R.K., Savell, J.W., Sams, A.R., Taylor, J.F., Sanders, J.O. \& Smith, S.B., 2006. Factors influencing the variation in tenderness of seven major beef muscles from three Angus and Brahman breed crosses. Meat Sci. 73, 475-483. 
Tyznik, W.J., 1992. Fundamentals of Animal Nutrition. Lab Manual. Kendall/Hunt Publishing Co, Dubuque, Iowa, USA.

Unlu, N., Yanar, M., Esenbuga, N., Ozluturk, A. Yuksel, S. \& Macit, M., 2008. Effect of days on feed on the performance and carcass characteristics of Eastern Anatolian Red young bulls. J. Appl. Anim. Res. 34, 163-168.

Voelker, J.A. \& Allen, M.S., 2003. Pelleted beet pulp substituted for high-moisture corn: 1. Effects on feed intake, chewing behavior and milk production in lactating dairy cows. J. Dairy Sci. 86, 3542-3552.

Yanar, M., 1994. Biochemical, histological and quality characteristics of mutton carcasses as affected by electrical stimulation and blade tenderization (Dissertation). The Ohio State University, Department of Animal Science, Columbus, Ohio, USA. 176 pp.

Yener, S.M., Akman, N. \& Ertugrul, M., 1988. Fundamental methods used by European Federation of Animal Science for evaluation of beef carcasses. Yem Sanayi Dergisi 58, 18-23. (in Turkish). 